\title{
The Institute for the History of Rheumatology, an offspring of the Italian Society of Rheumatology, is born in Venice
}

\author{
L. Punzi', A. Pérez Negrete', P. Marson², M.A. Cimmino'1, M. Po’3, \\ R. Gerli ${ }^{4,5}$, L. Sinigaglia ${ }^{1,5}$ \\ ${ }^{1}$ Istituto di Storia della Reumatologia, Venezia, Italy; \\ 'Unità di Aferesi Terapeutica, U.O.C. Immunotrasfusionale, Azienda Ospedale Università di Padova, Italy; \\ ${ }^{3}$ Scuola Grande di San Marco, Venezia, Italy; ${ }^{4}$ S.C. di Reumatologia, Dipartimento di Medicina e Chirurgia, \\ Università di Perugia, Italy; ${ }^{5}$ Società Italiana di Reumatologia, Italy
}

$\mathrm{R}$ heumatic diseases (RD), in particular gout and spondyloarthritis (SPA), are known to mankind from the remote past, and probably affected our progenitors (1). Although it is difficult to define the reasons for their early appearance, a possible explanation is the association of gout and SPA with innate immunity (2), our most ancestral defense system. Autoimmune diseases, such as rheumatoid arthritis, of which the onset was possibly of later date, were described anecdotally before the XVIII Century (3). Proof of the antiquity of RD is found in figurative art, literature, and paleopathology (4). There is a wealth of data sources in this field because RD, in particular gout, affected in the past many famous patients, treated by eminent physicians who left behind detailed information on their clinical features and therapy (5). These documents are largely unexplored to date; what is more, old commentaries should be revaluated in light of contemporary medical knowledge. A patient was Piero de' Medici, also known as "Piero the gouty", because of his severe disease. In contrast to this age-old diagnosis, recent paleopathology studies investigating genetics, revealed that he was affected by SPA, most probably psoriatic arthritis (6). Several Italian rheumatologists, including Camillo Benso Ballabio, Ugo Carcassi, Claudio Cervini and Gianpiero Pasero, were involved in studies on old records of RD. However, difficulties in the conservation of books and documents, especially in the hands of private concerns, have made their availability erratic to the point of hampering their scientific interpretation.

The Italian Society for Rheumatology (Società Italiana di Reumatologia, SIR) has confirmed its interest in this field by establishing the Institute for the History of Rheumatology (Istituto per la Storia della Reumatologia, ISR), to the best of our knowledge the sole dealing with a medical specialty, which has been located in the prestigious building of the Scuola Grande di San Marco in Venice.

\section{WHY VENICE, WHY THE SCUOLA GRANDE DI SAN MARCO?}

The ISR started its activity on October 12 , 2020, in the halls of the historical General Hospital of Venice that house the museum and cultural service of the Scuola Grande di San Marco (Figure 1). The association between this novel institution and the century-old Scuola is not fortuitous. Venice has enjoyed a historical medical tradition, especially in the modern era, which springs from its Byzantine tradition. Venice's solid relationship with Constantinople helped to rediscover Greek science and overcome medieval fabrications. In 1468 the Republic of Venice inherited Archbishop Bessarione's library, which comprised 482 Greek manuscripts, then the largest collection in the Western world, of which about 30 on medicine $(7,8)$. Perusal of these manuscripts and of medical literature in general was greatly enhanced by the great discov-
Corresponding author: Alberto Pérez Negrete, Istituto di Storia della Reumatologia, Campo SS Giovanni e Paolo,

Castello 6777

30122 Venezia, Italy

E-mail: istituto.storia.sir@reumatologia.it 


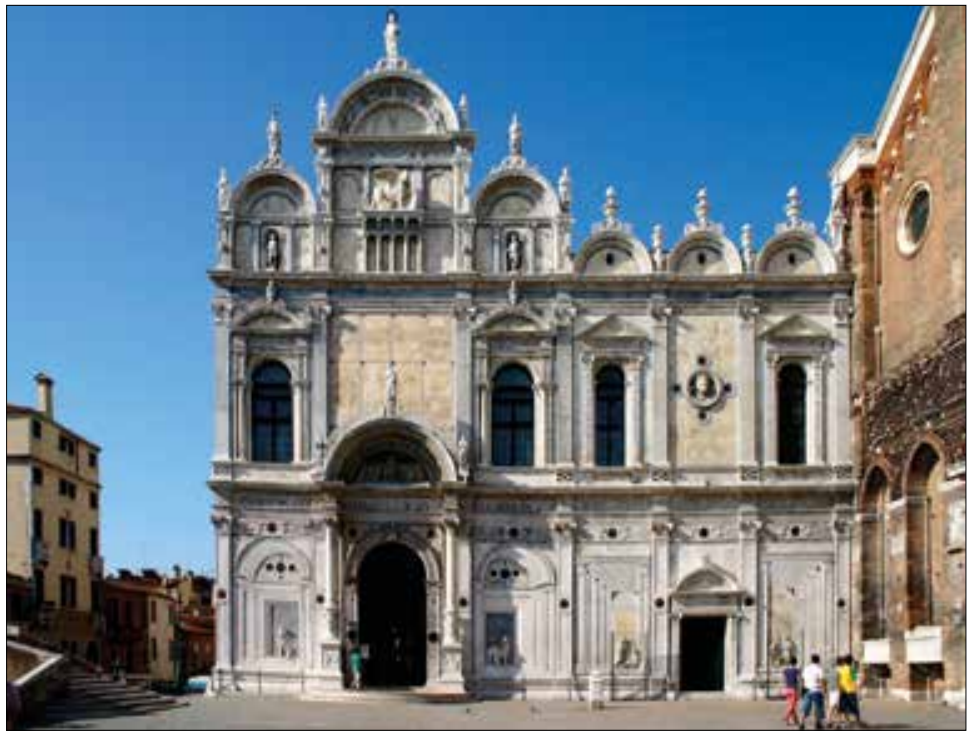

Figure 1 - Outside of the Civic Hospital SS. Giovanni e Paolo of Venice, formerly Scuola Grande di San Marco.

ery of the century: book printing with mobile characters of which Venice soon became a world leader $(9,10)$.

In the XV Century, about 660 physicians graduated in Venice, including Cardano, Da Monte, Mercuriale, and Tommaso Giannotti Rangone (11), a famous bibliophile. As much as those graduated from the Medical School of Padua (12), they lived in the medical Renaissance, when ancient art, not that constituted of ruins, archeological findings, and literature on Roman and Greek emperors and warriors, but that

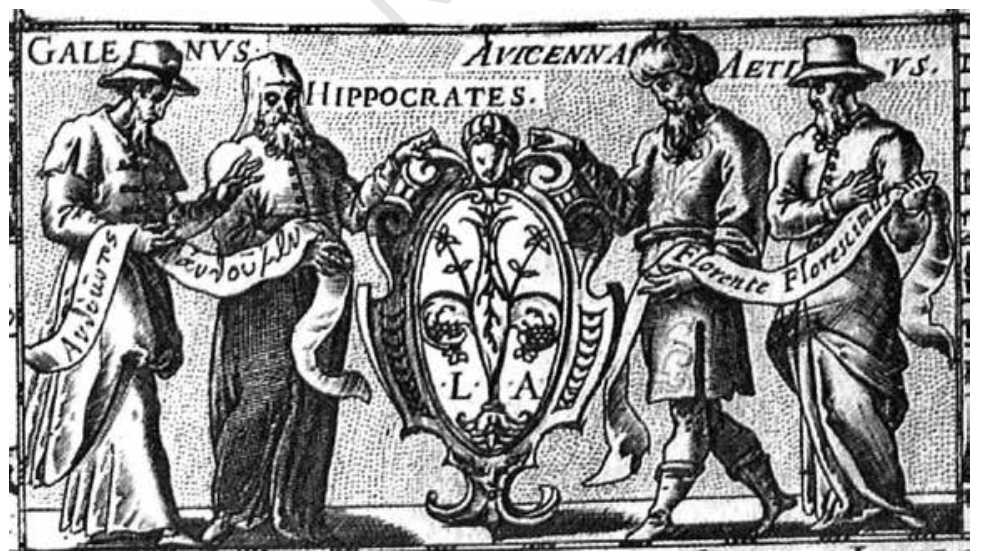

Figure 2 - Title page (detail), Hippocratis Coi Opera quae extant Graece et Latine veterum codicum collatione restituta, nouo ordine in quattuor classes digesta interpretationis Latinae emendatione, et scholijs illustrata, a Hieron. Mercuriali Foroliuiensis, Venezia, Lucantonio Giunta, 1588. based on classical texts of Hyppocrates, Galen, Celsus, and Avicenna, with their neo-platonic view of man as the center of the world (Figure 2). Based on their philosophical knowledge, they forged medicine as a mixture of the art of healing and science based on clinical observation and its rational explanation.

As a result, ISR was necessarily located in a great historical library, that, according to Umberto Eco, make immortal those who frequent it. It was founded at the end of the four-hundred in the old Dominican cloister of the Church of the holy Giovanni and Paolo. This was the provisional location of the Bessarione manuscripts, before Jacopo Sansovino built the palace that was to house the medical library of the Scuola Grande di San Marco. The library now has more than 500 books published between 1498 and 1799 (13), 14,000 books published in the following century, besides 900 journals and congress proceedings, which are shelved in different halls (Sala del bibliotecario, Sala degli Atlanti, Sala Capitolare, and Sala dell'Albergo). It is now complemented by publications dealing with studies on its historical collection. In the heritage works, the historical background of the rheumatology specificity, presently better known as specialty, can be found, as well as some testimony of the original efforts to translate clinical experience into scientific knowledge. Examples of it are the discoveries by Hippocrates $(14,15)$. The text of Aphorisms (Figure 3), belonging to the Corpus Hippocraticum, contains several observations on RD, such as gout, Behçet's disease, arthritis and sciatica, which in part are still valid. These are some of the most cited aphorisms regarding gout, known in the past as podagra (16), "eunuchs and children do not suffer from gout" (VI, 28: Eunuchi podagra non laborant, nec calui fiunt; VI, 30: Puer podagra non laborat ante veneris usum), and "women do no suffer from it before menopause" (VI, 29: Mulier podagra non laborat, nisi ipsam menstrua defecerint) (17). The 57 books by Galen are also impressing for their quality and quantity (Figure 4). Galen studied animal anatomy and 
physiology, in particular urine secretion by the kidneys, limb paralysis and sensorial disturbances after spinal nerves resection. $\mathrm{He}$ also differentiated sensitive and motor nerves, postulated the familial form of gout, and described tophi (18).

Another important book is the Liber Canonis (13) by $A b \bar{u}$ 'Ali Ibn Sinna, better known in the western world as Avicenna, based on the doctrines of Hippocrates, Galen and Aristotle. Originally written in

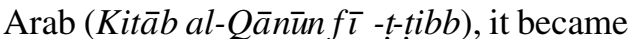
available in Europe in its Latin translation by Gerardo Da Cremona in the XII Century. This translation was later updated in the XVI Century by Andrea Alpago, physician of the Venetian consuls in Damascus and Cyprus (19).

Celsus defined the cardinal signs of inflammation in the De Re Medica (Notae vero inflammationis sunt quattuor: rubor et tumor cum calore et dolore) and three different types of fever, daily, tertian and quartan. He also stated that "fat urine, which yield white sediment, indicates that pain and the corresponding disease belong to the joints or inner organs". The Roman author agreed with the indications of Hippocrates on podagra saying that "the problems of the joints are more frequent and persistent in the hands and feet, as usually happens in podagra and chiragra. Rarely do these problems affect eunuchs, young boys before their sexual experience with women, or women themselves, except for those with interrupted menstrual cycle (...) some persons obtained safety for the rest of their life (of not being hit by gout) by reducing for as long as one year consumption of wine and mead, as well as sexual activity" (20).

Among the books published in the XV Century, The School Library contains masterpieces, such as those by Jacopo Berengario da Carpi and his treatise on surgery Tractatus perutilis et completus de fractura cranei; the De humani corporis fabrica by Andrea Vesalio (Figure 5); the Dictionarium Medicum by Henri Estienne; several works by Leonardo Fioravanti and Gabriele Falloppio; the Variarum Lectionum by Girolamo Mercuriale; several manuscripts

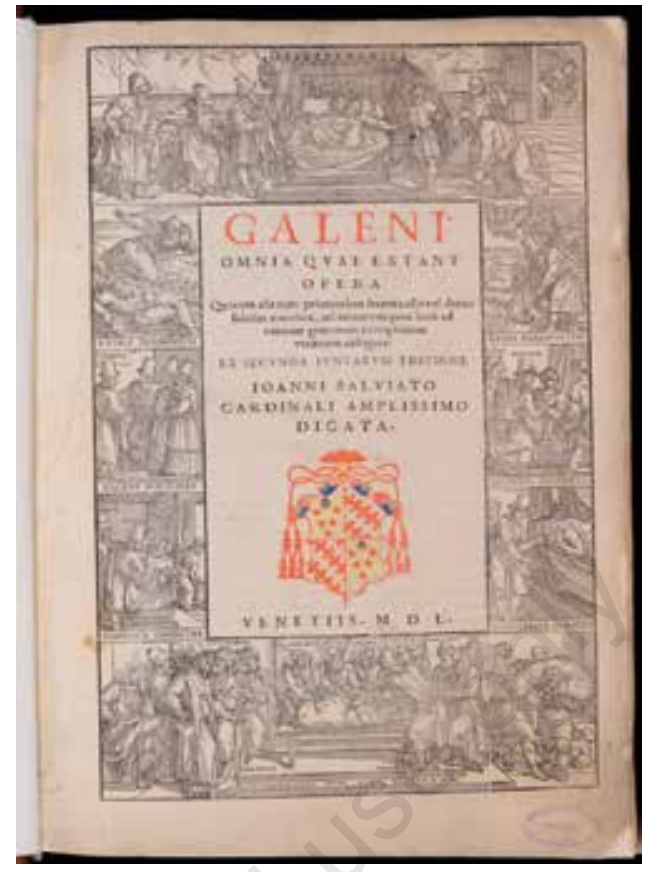

\section{Figure 3}

Title page, Galeni

In aphorismos

Hippocratis commentarii

septem, recens per

Gulielmum Plantium

Cenomanum Latinitate

donati eiusdemque

annotationibus illustrati.

Cum Priuilegio Regis.

Lione, Guillaume

Rouillé, 1551. by Girolamo Fabrici d'Acquapendente and others.

The richness of the Scuola is not only based on its library: this institution comprises also a Pathology museum, several paintings, projects and scale-models, ranging from the XIX Century to those of Le Corbusier, Luciano Semerani and Gigetta Tamaro, and surgical instruments used in

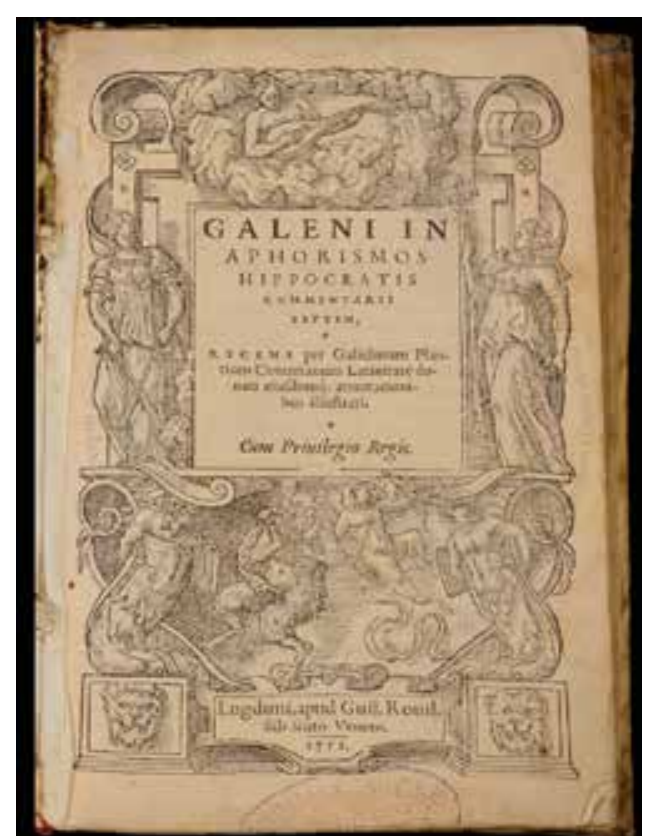

Figure 4

Title page, Galeni Omnia quae extant opera. Quorum alia nunc primum sunt inuenta: alia vel denuo fidelius translata, uel innumeris pene locis ad veterum Graecorum exemplarium veritatem castigata. Ex secunda luntarum editione. Ioanni Salviato Cardinali amplissimo dicata, Venezia, Lucantonio Giunta, 1550. 


\author{
Figura 5 \\ Title page, \\ Andreae Vesalii Anatomia, \\ Venezia, Giacomo \\ De Franceschi \\ e Johannes Antonius, \\ 1604.
}

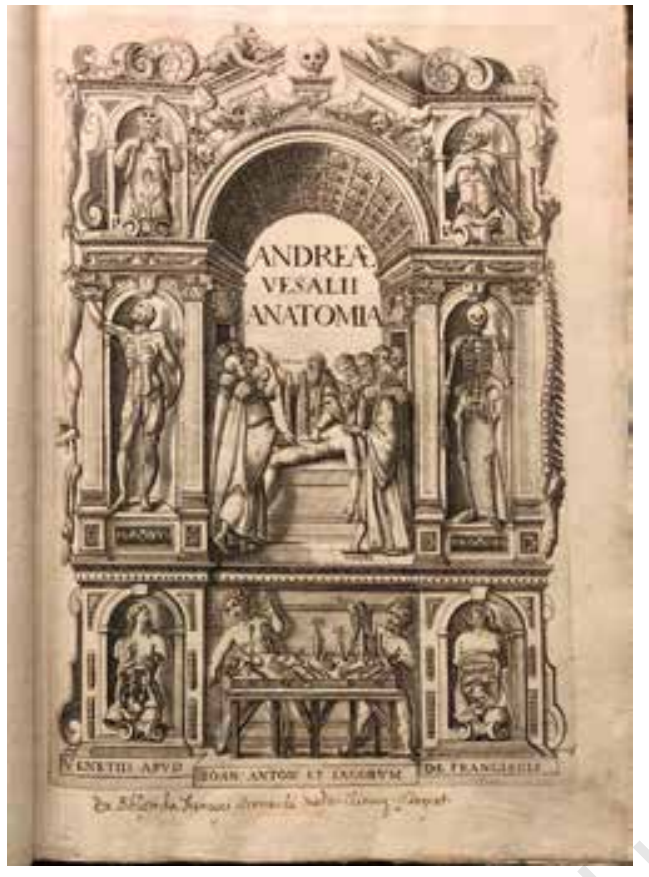

the Venice Hospital from the XVIII to the $\mathrm{XX}$ Century. To summarize, the Scuola protects the inherited treasure of more than six centuries of health history.

The ISR could not have found a better location for its birth and development, for it enjoys the privilege of sharing this precious bequest. These are the resources and the enabling circumstances that will make historical research in RD a fruitful field of investigation, through study of the past, analysis of the present and anticipation of the future. Rheumatology is a clinical area of great cultural and social import, not only because of the relevance of RD in today's society, but also because it is in the forefront of scientific and biotechnological research.

\section{REFERENCES}

1. Benedek TG, Rodnan GP. A brief history of the rheumatic diseases. Bull Rheum Dis. 1982; 32: 59-68.

2. Shin JI, Lee KH, Joo YH, et al. Inflammasomes and autoimmune and rheumatic diseases: A comprehensive review. J Autoimmun. 2019; 103: 102-299.

3. Pasero G, Marson P. Piccola storia delle malattie reumatiche. Pisa, Ed. Clinical and Experimental Rheumatology. 2006.
4. Rothschild BM. Contributions of paleorheumatology to understanding contemporary disease. Reumatismo. 2002; 54: 272-84.

5. Pasero G, Marson P. I geni della gotta. Reumatismo. 2005; 57: 140-1.

6. Fornaciari G, Giuffra V. The "gout of the Medici": making the modern diagnosis using paleopathology. Gene. 2013; 528: 46-50.

7. Derenzini G. La biblioteca di Bessarione a Venezia. In: La scienza a Venezia tra Quattrocento e Cinquecento. Opere manoscritte e a stampa. Catalogo della mostra, Venezia, 3-15 ottobre 1985, Stamperia di Venezia, 1985: 11-33.

8. Zorzi M. I codici di argomento medico della Biblioteca Marciana. In: Vanzan Marchini NE. Dalla scienza medica alla pratica dei corpi: fonti e manoscritti marciani per la storia della sanità. Vicenza: Neri Pozza, 1993: 17-44.

9. Einsenstein EL. The printing press as an agent of change: Communications and cultural transformations in early Modern Europe. Cambridge: Cambridge University Press. 1979.

10. Andreoli I. Anatomie libresche: il libro di medicina nel primo secolo della stampa. In: Matino G, Klestinec C. Arte, fede e medicina nella Venezia di Tintoretto. Venezia: Marsilio. 2018: 105-15.

11. Minuzzi S. Tommaso Giannotti Rangone: una vita modellata sui libri e sull'arte (non solo medica). In: Matino G, Klestinec C. Arte, fede e medicina nella Venezia di Tintoretto. Venezia: Marsilio. 2018: 43-58.

12. Ongaro G. Il Cinquecento medico padovano. Padova e il suo territorio. 2020; 35 (fasc. 208): 42-45.

13. Spina L. Le Cinquecentine della biblioteca medica San Marco. In: Vanzan Marchini NE. La Scuola Grande di S. Marco: i saperi e l'arte. Treviso: Canova. 2001: 99-109.

14. Pasero G., Marson P. Hippocrates and rheumatology. Clin Exp Rheumatol. 2004; 22: 687-9.

15. Squillace G. Le malattie del rheuma nel Corpus Hippocraticum. Reumatismo. 2007; 59: 1-5.

16. Punzi L, Ramonda R. Gotta (artrite da urato monosodico). In: Punzi L, Doria A. Core Curriculum. Reumatologia. Milano: McGraw-Hill Education, 2014: 185-99.

17. Byl S. Rheumatism and gout in the Corpus Hippocraticum. L'Antiquité Classique 1988; 57:89-102.

18. Cosmacini G., Menghi M. Galeno e il galenismo: scienza e idee della salute. Milano: Franco Angeli, 2012.

19. Lucchetta F. Il medico e filosofo bellunese Andrea Alpago (1522) traduttore di Avicenna: profilo biografico. Padova: Antenore, 1964.

20. Leca AP. Histoire illustrée de la rhumatologie. Goutte, rhumatismes, et rhumatisants. Paris: Les Éditions Roger Dacosta, 1987. 